\section{Moscow seminar threat}

The Moscow Sunday seminars for Jewish refusnik scientists, which have been held (official harassment permitting) since 1973, now face a new threat. Last Friday, Dr Irina Brailovskaya was informed by the deputy chairman of the local municipal council that if she continued to host the seminars, she and her whole family would be liable to internal exile.

This official told Dr Brailovskaya that there had been complaints from the neighbours about the holding of the seminars. "We do not object to scientific meetings", he explained, "but the devil only knows what is going on here!"

The seminars have only recently resumed after a KGB clamp-down last autumn. Following the arrest of $\mathrm{Dr}$ Viktor Brailovskii, on 13 November, for several weeks the apartment was surrounded on Sundays by security police who turned away intending participants. Early in the new year, the seminars resumed on Saturday evenings, and then, a few weeks ago, reverted to the traditional Sundays.

In a recent message to Western scientists, Dr Brailovskaya said that her husband has been held in custody beyond the legal limit (three months) within which he should have been either charged or released. $\mathrm{He}$ is, she said, in a poor state of health, suffering from chronic hepatitis and a blockage of the gall duct.

auspices seem good for renewed East-West cooperation. President Reagan's assistant secretary designate on human rights, Dr Ernest Lefever, is reported to favour keeping such matters distinct from international politics. The several thousand Western scientists who signed personal moratoria pledges bound themselves to limit their contacts with the Soviet Union only until the end of the Madrid conference. However, at the meeting of the United Nations human rights commission in Geneva last week, a motion from the Canadian delegation was dropped from the agenda.

Vera Rich

\section{Science education}

\section{Tap turned off}

\section{Washington}

The Reagan Administration is proposing to eliminate all support at US universities for undergraduate and graduate science students at present provided by the National Science Foundation.

The cuts are part of a plan to phase out the foundation's responsibilities for science and engineering education, justified by the claim that these are of lower priority than the need to support basic research. But the proposed cuts may have been partially instigated by conservatives upset by some of the foundation's educational activities.
The cuts would eliminate several programmes introduced over the past few years, primarily at the direction of Congress. These include support for women, minorities and "talented individuals" in science, strengthening science teaching in middle and high schools, and efforts to improve public understanding of science.

The new Administration argues that such efforts are of low priority, and that they are too broadly spread and narrowly focused to have any significant effect. Science teaching has, however, always been treated better by Congress than by either the National Science Foundation itself or the Office of Management and Budget; and there remains a good chance that some of the money will be put back during the congressional review process.

In response to the report last year by the foundation and the Department of Education which drew attention to the growing "scientific illiteracy" among the US public and to concern over the lack of adequate technical graduates in fields related to energy and military technology, President Carter had proposed in January that the 1982 budget for the foundation should include an allocation of $\$ 119.9$ million for science and engineering education, a significant increase over the $\$ 80.7$ million allocated in the current year.

In contrast, the new Administration suggests that the current budget be reduced to $\$ 64.7$ million, and that support for science and engineering education next year be reduced to $\$ 9.9$ million. All of this sum would be used to meet existing commitments to students receiving fellowships.

Other cutbacks include the elimination of three major programmes: science education resources improvement ( $\$ 21.8$ million in 1980), aimed at improving undergraduate instruction in two- and four-year colleges by upgrading instructional equipment and teacher competency; science education development and research (\$13.8 million) for developing new and more effective materials and methods of instruction in science and engineering; and science education communication ( $\$ 8.5$ million).

Reaction to the proposed cuts has been sharp. Dr Alan Bromley, professor of physics at Yale University and president of the American Association for the Advancement of Science, warned that "to expect scientific and technological progress while abandoning efforts at improving science and engineering teaching in our schools is illogical and a disservice to the nation's interest". The association had previously announced that science education was to become a principal target of its own efforts over the coming year.

Dr Gerald Liebermann, dean of research at Stanford University, last week voiced the universities' anxieties: "In the past we have had to put little of our general funds to the support of graduate students in

\section{Argentinians face charges}

Dr Jose Federico Westerkamp, formerly professor of physics at the University of Buenos Aires, was arrested on 27 February 1981 during a police raid on the human rights organization CELS (Centro de Estudios Legales y Sociales, Centre for Social and Legal Studies). He was held in custody for a week, then released. Police investigations into his human rights activities are, however, continuing.

Dr Westerkamp, who had been active on behalf of human rights in Argentina for several years, was a co-founder of CELS, together with two lawyers - Dr Emilio Fermin Mignione and Dr Augusto Conte Mac Donell. The group, which was set up early in 1979 and legally registered in March 1980, investigates human rights abuses, including the defence of political prisoners and the gathering of data on "disappeared" persons. Dr Westerkamp, whose son Gustavo has been a political prisoner since 1975 , has been particularly active on behalf of imprisoned and "disappeared" scientists and academics, and has on numerous occasions spoken on their behalf at international scientific meetings.

According to the Argentinian newspaper, La Razon, CELS members face charges under article 224 for possessing plans and diagrams of military installations, carrying a possible penalty of two to eight years imprisonment.

science and engineering, but it is likely that we will now have to reevaluate our whole policy in this area". Dr John C. Crowley, of the Association of American Universities, claims that the cuts would wipe out "one of the two functions for which the foundation was established" and "calls into question the basic purpose of the National Science Foundation"'.

At the foundation itself, where it has been frequently claimed that science education has received less support than basic research, officials admitted that the cuts were "hard to square" with the report presented to President Carter last autumn.

Federally-sponsored science education programmes have some powerful opponents on the right. Some argue that, in principle, the federal government should play a minimal role in curriculum development, leaving it to state and local schools boards; others have criticized the foundation's education activities in the past, for example in developing biology and social science courses which, they claim, reinforce "relativist" values by portraying man and woman as part of nature, rather than unique creations. The cuts in the science education budget seem to have been orchestrated by groups such as the conservative Heritage Foundation and are likely to receive support from conservative members of Congress.

David Dickson 